\title{
Effectiveness Model of Literacy Education Oriented to Local Culture
}

\author{
Uyu Wahyudin \\ Lecture, Department of Nonformal Education, \\ Universitas Pendidikan Indonesia \\ Indonesia, Bandung \\ wahyudin.pls@upi.edu
}

\begin{abstract}
The present study stems from the fact that implementation of the local culture approach in literacy education is not optimal. It aims to develop a functional literacy education model oriented to local culture for the improvement of learning quality in learning groups provided by Community Learning Centers (CLCs). The method used in this study is a research and development, combining qualitative and quantitative approaches. The result from this research explain that the model of literacy education with local culture orientation and the quality of learning developed in this study has high use in functional level.
\end{abstract}

\section{Keywords - functional literacy education, local culture}

\section{INTRODUCTION}

Literacy is an ideology, consisted of a series of ideas, beliefs, and behaviors that simultaneously shape public perception on literacy itself. In its position as an ideology, literacy movement should engage total participation of everyone in a community. As such, ideology to be used in literacy program is the ideology of the community or the learners. Literacy program should accommodate the views of all learners participating in the program. These views or perceptions will be clearly represented in cultural values.

Kusnadi [1] In the unique condition of Indonesia that is rich with various cultures, traditions, ethnicities, religions, and beliefs, it is impossible to implement one or two literacy philosophies. Literacy program in Indonesia should implement a combination, sublimation, and integration of the philosophies of critical literacy, political literacy, spiritual literacy, cultural literacy, women literacy, family literacy, and contextual literacy The implementation of literacy education in Indonesia should consider the diversity of learners' culture since the existing literacy education programs are still nationally homogeneous, non-adaptive, and unable to accommodate the specific dimensions of local cultures.

Literacy education programs implemented today still causes some problems that need in-depth investigation to solve. The most frequently found problems include the lack of professional management and the low quality of learning service delivered by the tutors and the management. Several regencies with high prevalence of poverty and illiteracy in Indonesia reported weaknesses in the management of literacy program; in its preparation, implementation, coordination, and monitoring aspects. Other problems pertaining to literacy program implementation include the high level of drop out, insufficient and inadequate facilities, unclear learning model, scarcity of textbooks, lack of highly trained tutors, and inappropriate target (Ditjen PLSP and BPS, 2004).[2]

Up to the present, the learning used in literacy education program focuses more on national language; it has not been adjusted to the characteristic of local cultures in the society. The learning materials used by the tutors are homogeneous in all regions. There are only few literacy learning tools developed based on local cultures of the learners. Such learning will not bring significant changes in learners' achievement of basic competencies mastery; particularly that pertains to the preservation of cultural values in the society. Current literacy programs will only generate conventional learning process which is not innovative and only adding to the knowledge that learners already possess. Not to understate its benefit, the knowledge that learners acquire is not sufficient to play the role of preserving cultural values, which are the main component of national identity. Therefore a functional literacy education program that develops cultural characteristics that pertains to the learners' cultures is needed.

Considering the problems of functional literacy education nowadays and the ability and skills of the management and tutors, an investigation on the effectiveness of the model of literacy education oriented to local culture is needed to solve them. As such, the research problem is formulated as: "How effective the model of literacy education oriented to local culture in significantly reducing the numbers of illiterates and improving learners' competencies?'

To facilitate the problem solving process, the research problem is formulated into research questions:

- How is the empirical condition of functional literacy education in the field?

- How is the management of the model of literacy education oriented to local culture?

- What are the obstacles in implementing literacy education oriented to local culture? 
- How is the effectiveness of the model of functional literacy education with local culture? .

\section{RESEARCH METHOD}

The study implements qualitative approach, with research and development design as its procedure. Borg and Gall, (1989), [3] says "Educational Research and Development is a process used to develop and validated educational products".

Data is collected through questionnaire, interview, and documents study. The sample of the study is 5 members of CLC management, 10 public figures, 10 tutors, and 100 learners (50 learners in the experimental group and 50 learners in the control group). The sample is distributed in five Community Learning Centers (CLCs) in five sub-districts; i.e. Cipunagara, Pagaden, Cijambe, Cisalak, and Tanjungsiang subdistricts. Data is analyzed using qualitative and quantitative (path analysis and t-test) approaches.

\section{RESULTS OF THE STUDY}

\section{A. The Empirical Condition of Literacy Education}

Regional government of Subang Regency [4] (particularly the Department of Education) has implemented the national policy of National Illiteracy Alleviation Movement seriously. The implementation is supported by the spirit of 'working together', reflected in various forms, including: (1) the registration of all potential learners, involving all elements in all levels related with the program; (2) gradual training of functional literacy program tutors; (3) the implementation of functional literacy program that involves the participation of all concerned organizations/institutions; (4) the partnership with concerned institutions, including universities (UPI, UGM) and the Center of Non-Formal and Informal Education Development (P2PNFI) Regional I Jayagiri, West Java (presently called P2PAUDNI); (5) the provision of facilities and infrastructures by the government and the community.

The model of functional literacy education with local culture orientation is empirically proven to improve learners' mastery of basic competencies. The elements of local culture are developed and embedded in learning curriculum, learning materials, learning strategies and media, and learning evaluation instruments. Although all components are delivered in Sundanese, the competencies targeted by the programs still refer to the standard literacy competency (SKK). The local culture is reflected in the formulation of learning components; which are closely related with learners' culture. In literacy education, the utilization of Sundanese as the language of delivery may form a strong foundation of learning and is an important bridge to learn Bahasa Indonesia. Learners are gradually encouraged to use both languages in the context of lifelong learning. [5]

Beside that, the learner in functional literacy program many from adult, Knowles (1980) citation in Cornelius-White, presents five assumptions underlying andragogy. These describe the adult learner as being an individual who: Is independent and wanting to direct their own learning; has learning needs related to changing social roles; has an 'accumulated reservoir of life experiences'; is problemcentered and interested in immediate application of knowledge; and is primarily motivated by intrinsic rather than extrinsic factors. A key differentiator between the adult classroom and the child's classroom is the existence of mutuality between teachers and students as 'joint inquirers'. In other words, adult curriculum should be student-directed as opposed to teacher-directed [6] [7]

\section{B. The Management of Functional Literacy Education}

The management of learning is essentially carried out in three stages [8]: (1) planning stage; (2) implementation stage; and (3) evaluation stage. The principles of literacy education program are [9]: (a) local context, in which learning strategies, materials, media, and evaluation should conform with learners' local culture, language, and potentials; (b) local design, which means that the learning program is designed by the tutors and the management in cooperation with the learners, so that the themes/topics of learning are developed based on learners' needs analysis; (c) participative, which means that the learning process should involve learners as much as possible in the planning, implementation, and evaluation stages; (d) Optimization of the results of functional literacy program (reading, writing, and numerical skills); in which the learners are expected to apply them in their daily life.

Learning methods used in the programs include: (a) structure analysis and synthesis (SAS) method that utilizes an approach of reading sentences, which are then analyzed in words and syllables, and recombined into sentences; (b) keywords method that teaches reading through familiar words; (c) association method that teaches reading through pictures; (d) global method that focuses on key sentence, including its form, spelling, and meaning, which is broken down into words, syllables, and letters; (e) alphabets method that teaches reading by combining letters, spelled in alphabets.

Learners' participation in learning management provides several benefits: (1) higher achievement, (2) better learning quality, (3) higher motivation to achieve, (4) a sense of acceptance due to emotionally and mentally engaged during the learning process, (5) higher self-esteem in the part of the learners, (6) the development of cooperation among learners, (7) higher willingness to achieve goals, (8) lower rate of absent from class.

The findings concerning the implementation of functional literacy education management are presented in the following diagram 


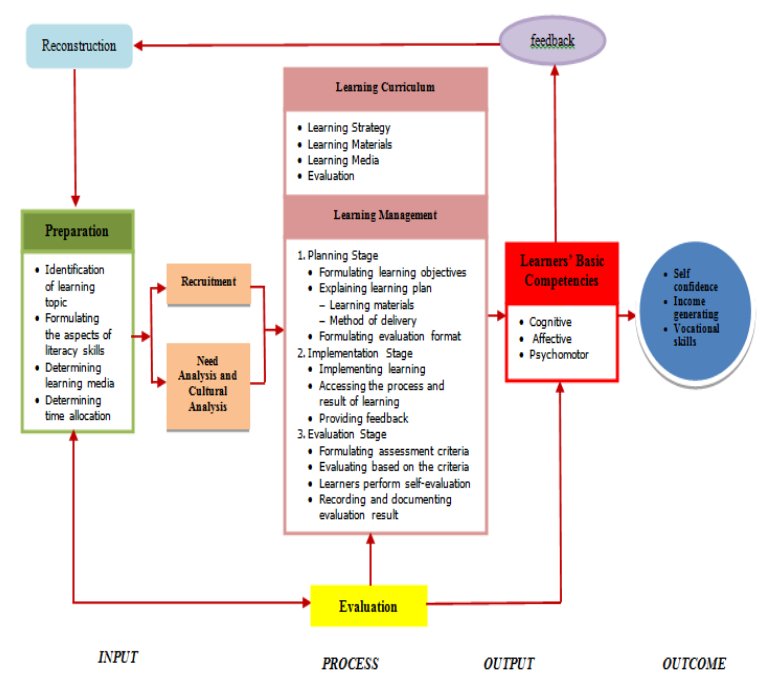

\section{Obstacles in Functional Literacy Education Program}

The obstacles in the implementation of functional literacy education program come from internal and external factors of the learners. The obstacles are: first, Bahasa Indonesia, as the formal language to deliver the program, still provides an obstacle in communication which causes the learning process to be not smooth and passive; second, learners have not actively expressed their ideas concerning the topics of learning; third, there is insufficient number of references and learning materials with local culture orientation in the five sites of the study; fourth, the learners lack motivation to study the reading materials; fifth, the tutors do not have sufficient skills to prepare easy-to-understood materials that learners need; sixth, the learners are unable to recognize their potentials due to their lack of awareness, understanding, and sensitivity of themselves and of external problems that rapidly change; seventh, the tutors do not prepare evaluation instruments (such as tests) but directly evaluate the learners' development through correcting the latter's writing or reading.

\section{Effectiveness of the Model of Functional Literacy Education with Local Culture Orientation}

The management of literacy education with local culture orientation is proven to be significantly effective to improve the learners' mastery of basic competencies. Elements of local culture are developed and embedded in learning curriculum, learning materials, learning strategies and media, and learning evaluation instruments. It is effective as the media that facilitates learners to understand the materials delivered by the tutors, reflected in learners' mastery of basic competencies. The quality of learning management, the quality of learning service, and the learners' functional literacy competencies has positive and significant correlation among each other.

\section{DISCUSSION}

The findings of the study in general result in the following conclusions: (1) learners are unable to recognize their potentials due to their relatively low awareness, understanding, and sensitivity of themselves and of the external problems that rapidly change; (2) the model of functional literacy education quality oriented to local culture significantly improve the learners' mastery of basic competencies. Elements of local culture are developed and embedded in learning curriculum, learning materials, learning strategies and media, and learning evaluation [10] ; (3) the implementation of functional literacy education model oriented to local culture is delivered in three stages: the preparation, the implementation, and the evaluation stages; (4) the quality of learning in the group that implement the model (experimental group) is better than that in the learning group that does not use the model in its learning intervention (control group). The quality of learning management, the quality of learning service, and the learners' functional literacy competencies has positive and significant correlation among each other [11]. The quality of management and the quality of service, both partially and simultaneously, have significant and positive correlation with learners' basic functional literacy competencies. [12]

\section{CONCLUSIONS}

Based on these conclusions, the model of literacy education with local culture orientation and the quality of learning developed in this study has high use in functional level. Substantially, it can strengthen the rational foundation for the implementation of literacy education using innovative strategies to accommodate cultural diversity in the community.

\section{REFERENCES}

[1] Kusnadi et al. (2005), Pendidikan Keaksraan Filosofi, Strategi, Implementasi, Jakarta : Ditjen PLS

[2] Direktorat Jenderal Pendidikan Luar Sekolah dan Pemuda. (2006). Keaksaraan Melalui Bahasa Ibu. Jakarta: Depdiknas

[3] Borg, W. R. et.al., (1989). Educational Research. New York:Pitman Publishing

[4] Dinas Pendidikan Kabupaten Subang. (2006). Statistik Pendidikan Kabupaten Subang. Subang: Dinas Pendidikan Kabupaten Subang

[5] Hufad, A. (2004). Sosialisasi Indentitas Kekerabatan Pada Keluarga Inti. Disertasi Doktor pada PPS UNPAD Bandung: tidak diterbitkan.

[6] Cornelius-White,.JH. (2010). Learner-Centered Instruction: Building Relationships for Student Succes. Thousand Oaks, CA: Sage.

[7] Knowles, Malcolm S., Elwood F. Holton III, \& Richard A. Swanson. (1998). The Adult Learner. Houston: Gulf Publishing.

[8] Terry. (1978). Programming Learning Aid : Principles of Management. Homewood, illionis : Rechard D. Irwin, Inc.

[9] Faisal. S. (2006). Paradigma Baru Pendidikan Keaksaraan Tawaran Bagi Pengembangan Program Keaksaraan di Indonesia. Prasaran pada Seminar dan Lokakarya Nasional Pendidikan Keaksaraan di Solo.

[10] Abdulhak, I, (2000). Metoda Pembelajaran Pendidikan Orang Dewasa. Bandung: UPI Press.

[11] Bhola. (1994). A. Sources Book for Literacy Work. Persepective from the Grass Roots, London : UNESCO Publishing. 
[12] Parasuraman, A., Zeithaml, V.A. and Berry, L.L. (1993). "Research note: more on improving service quality measurement", Journal of
Retailing, Vol. 69, No. 1, pp. 140-147. 